Full-length article

\title{
Increased secretion and expression of amylin in spontaneously diabetic Goto-Kakizaki rats treated with rhGLP-1 (7-36) ${ }^{1}$
}

\author{
Hong-bo WENG ${ }^{2}$, Qian $\mathrm{GU}^{3}$, Meng $\mathrm{LIU}^{3}$, Neng-neng $\mathrm{CHENG}^{2}$, Duan $\mathrm{LI}^{2,4}$, Xin $\mathrm{GAO}^{3,4}$
}

Department of ${ }^{2}$ Pharmacology, School of Pharmacy and Department of ${ }^{3}$ Endocrinology, ZhongshanHospital, Fudan University, Shanghai 200032, China

\section{Key words}

amylin; islet amyloid polypeptide; insulin; glucagon-like peptide 1; Goto-Kakizaki rats; type 2 diabetes

${ }^{1}$ Project supported by a research fund for the Doctoral Program of Higher Education (No 2004-024-6069) and the Shanghai Science and Technology Development Foundation (No 064909002).

${ }^{4}$ Correspondence to Prof Duan LI and Prof Xin GAO

Phn 86-21-5423-7167.

E-maildli@shmu.edu.cn (Duan LI)

Phn 86-21-6443-9025.

E-mail gao.xin@zs-hospital.sh.cn (Xin GAO)

Received 2007-11-03

Accepted 2008-01-25

doi: $10.1111 /$ j.1745-7254.2008.00782.x

\begin{abstract}
Aim: To investigate the effect of recombined human glucagon-like peptide 1 (rhGLP-1 [7-36]) on the secretion and expression of amylin in Goto-Kakizaki (GK) rats. Methods: The GK rats were treated with rhGLP-1 (7-36) 56 and $133 \mu \mathrm{g} \cdot \mathrm{kg}^{-1}$ subcutaneously for 12 weeks. The fasting and post-prandial blood glucose levels were measured. The plasma amylin concentration was measured by ELISA. The transcription levels of amylin and insulin mRNA were evaluated by fluorescent-quantitative-PCR. Immunohistochemistry was utilized to detect the amylin protein. Histological examination was assayed by light microscopy. Results: Treatment with rhGLP-1 (7-36) caused a significant reduction of post-prandial blood glucose levels in the GK rats $(P<0.05)$. The plasma amylin levels of the GK rats were lower than those of Wistar rats after the glucose administration $(P<0.01)$. Treatment with rhGLP-1 (7-36) exhibited a marked elevation of the glucose-stimulated plasma amylin level $(P<0.05)$ and slight histological amelioration. The amylin expression was augmented in the rhGLP-1 (7-36)-treated GK rat pancreas. Amylin and insulin mRNA were also highly expressed in the treated GK rats $(P<0.05)$. However, the ratio of amylin to insulin mRNA was significantly decreased by treatment with rhGLP-1 (7-36). Conclusion: RhGLP-1 (7-36) stimulates the secretion and expression of amylin, and exerts a beneficial effect on the ratio of amylin to insulin mRNA. These findings suggest that GLP-1 and GLP-1 analogs are ideal candidates for the treatment of type 2 diabetes.
\end{abstract}

\section{Introduction}

Type 2 diabetes is a chronic metabolic disease, which is characterized by fasting hyperglycemia that worsens as the disease progresses. Data from the UK Prospective Diabetes Study (UK-PDS) have shown that an almost inevitable progressive $\beta$-cell failure occurs despite the use of various therapies aimed at ameliorating hyperglycemia ${ }^{[1]}$. Several mechanisms may contribute to the progressive $\beta$-cell failure in type 2 diabetes, including loss of $\beta$-cell mass, $\beta$-cell exhaustion, and the cytotoxic effects of elevated glucose and lipid levels. A growing body of evidence suggests that islet amyloid deposits may play an important role in the loss of $\beta$-cells and the progressive decline in insulin secretion ${ }^{[2]}$. Westermark et al ${ }^{[3]}$ identified the major component of islet amyloid as a 37 amino acid peptide and named it amylin or islet amyloid polypeptide. In type 2 diabetes, this peptide aggregates to form amyloid fibrils that are toxic to $\beta$-cells $\mathrm{s}^{[4]}$. The mechanism responsible for islet amyloid formation in type 2 diabetes is still unclear, but it appears that an increase in the secretion and expression of amylin ${ }^{[5-6]}$ can result in its onset.

Amylin is colocalized with insulin in the isle $\beta$-cells and is cosecreted with insulin in response to $\beta$-cell stimulation by both glucose and non-glucose secretagogues agents, such as arginine ${ }^{[7]}$. Therefore, therapies that alter endogenous insulin secretion are likely to cause parallel changes in amylin secretion. In fact, previous studies have suggested that sulfonylurea therapy increases the post-prandial amylin concentration, but not so in insulin therapy ${ }^{[8]}$. These changes in turn may influence the rate of the formation of 
islet amyloids, which may be disadvantageous in the long term.

Glucagon-like peptide 1 (GLP-1) is an incretin hormone secreted from the intestinal L-cell in response to meal ingestion. In the pancreas, GLP-1 stimulates meal-induced insulin secretion in a glucose-dependent manner, dramatically lowering post-prandial glucose levels ${ }^{[9,10]}$. More recently, the direct effects on $\beta$-cell growth and survival have been identified, with the GLP-1-stimulated proliferation and differentiation of new $\beta$-cells leading to increased $\beta$-cell mass ${ }^{[11-13]}$. Furthermore, GLP-1 delays gastric emptying. These observations support GLP-1 as a novel candidate for the treatment of type 2 diabetes. However, it is not clear whether GLP-1 would elevate the amylin concentration, like sulfonylurea, which would weaken its effectiveness on diabetes therapy.

The Goto-Kakizaki (GK) rat has been used as an animal model for type 2 diabetes. This animal is a non-obese, spontaneously-diabetic rat produced by selective inbreeding of Wistar rats with the highest glucose values during oral glucose tolerance tests. In vitro investigations of the perfused pancreas of GK rats as well as of diabetic animals in vivo have revealed an impairment of the glucose-induced release of insulin. Further, histological studies have shown an irregular shape of some, but not all, islets in GK rats aged 3 months or older ${ }^{[14,15]}$.

The purpose of this study was to examine the effect of the GLP-1 derivative, recombined human GLP-1 [rhGLP-1 (7-36)], on the fasting and post-prandial amylin concentrations and islet amylin and insulin mRNA levels to determine whether amylin secretion would be altered in a way that might affect the action of insulinotropic drugs in GK rats.

\section{Materials and methods}

Rats Male spontaneously-diabetic GK rats (34 weeks old) and non-diabetic Wistar rats were supplied by and bred at Shanghai Slac Laboratory Animals. The rats were housed under controlled conditions of constant temperature and humidity.

Experimental protocol There were 4 groups in the experiment. The Wistar rats were used as the normal control group. The GK rats were divided randomly into 3 groups. The first group, which was given saline solution, served as the vehicle-treated group; the other two groups were given rhGLP-1 (7-36), $56 \mu \mathrm{g} \cdot \mathrm{kg}^{-1}$ for the GK/GL (given GLP-1 low dose) group and $133 \mu \mathrm{g} \cdot \mathrm{kg}^{-1}$ for the GK/GH (given GLP-1 high dose) group by subcutaneous injection ter in die (tid) for 12 weeks, respectively (provided by Shanghai Huayi Biolab, Shanghai, China).
Measurement of blood glucose In each rat group, the body weight and fasting blood glucose (overnight fasting for $18 \mathrm{~h}$ ) were monitored at $0,1,3,5,7$, and 11 weeks of the treatment with rhGLP-1 (7-36). In the 11 th week, the postprandial blood glucose level was measured at 30 and $60 \mathrm{~min}$ after feeding by the Roche Glucotrend-2 glucometer (Lewes, East Sussex, UK) ${ }^{[16]}$.

Intraperitoneal glucose tolerance test ${ }^{[17]}$ and the measurement of plasma amylin In the 12th week of treatment following overnight fasting for $18 \mathrm{~h}$, the rats were subjected to an intraperitoneal glucose tolerance test (IPGTT). A glucose solution $\left(20 \%, 1 \mathrm{~g} \cdot \mathrm{kg}^{-1}\right.$ body weight) was injected intraperitoneally, and blood samples were collected from the ophthalmic vein at $0,15,30,60,120$, and $180 \mathrm{~min}$ after the glucose injection. The blood glucose levels were measured using the Roche Glucotrend-2 glucometer ${ }^{[16]}$. The samples were centrifuged at $4{ }^{\circ} \mathrm{C}$. The plasma samples were stored at $-20^{\circ} \mathrm{C}$ until the assay. Plasma amylin was determined using an ELISA kit (Uscn Life Science and Technology, Missouri City, TX, USA) based on the standard curve ${ }^{[18]}$. Directly after the glucose tolerance test, the rats were killed by dislocation of the cervical vertebra, and the pancreatic tissues were taken for further studies.

Histological examination The rat pancreata were fixed in $10 \%$ neutral buffered formalin and embedded in paraffin. Each pancreatic block was serially sectioned $(6 \mu \mathrm{m})$ to avoid any bias from regional changes in islet distribution and islet cell composition; the sections were then mounted on slides. Then 10 sections were randomly chosen at a fixed interval throughout the block. Half the sections were stained with hematoxylin-eosin (HE) for light microscopy.

Examination of islet number In total, 45 sections stained with HE were chosen from each group. The number of islets in each section was counted in 10 random, non-overlapping fields under light microscopy (magnification $\times 250$ ).

Immunohistochemistry For the immunohistochemical demonstration of amylin, the streptavidin-biotin-peroxidase complex (SABC) technique was employed ${ }^{[19,20]}$. After routine deparaffinization, rehydration, and blocking of endogenous peroxidase activity, the sections underwent antigen retrieval. Subsequently, the sections were incubated with a rabbit antiserum against rat amylin (AssayPro, Winfield, MO, USA) antibody diluted at 1:100 in phosphate-buffered saline, followed by incubation with biotinylated antirabbit immunoglobulin G (IgG; Boster, Wuhan, China) and SABC reagent incubation. Staining was visualized by incubation with 3,3'diaminobenzidine-tetrahydrochloride (Boster, China). The sections were counterstained with hematoxylin, mounted in a neutral gum, and examined under light microscopy. 
Fluorescent-quantitative PCR The total RNA of the samples was extracted with Trizol (Invitrogen, Carlsbad, CA, USA) according to the manufacturer's instructions. Reverse transcription (RT) of RNA was performed with a M-MLV reverse transcriptase (Promega, Madison, WI, USA). The primers used for the amplification of insulin were: 5'CAAACAGCACCTTTGTGGTCC-3' (forward) and 5' -TCCACAATGCCACGCTTCT-3' (reverse), and for amylin: 5'-AGCTGTTCTCCTCATCCTCTCG-3' (forward) and 5'TGCCACATTCCTCTTCCCAT-3' (reverse). The RT reaction was incubated at $37^{\circ} \mathrm{C}$ for $1 \mathrm{~h}$ and inactivated at $90{ }^{\circ} \mathrm{C}$ for 10 min. Fluorescent-quantitative (FQ)-PCR was applied to quantify amylin and insulin mRNA in GK rat pancreata.

The $25 \mu \mathrm{LFQ}-\mathrm{PCR}$ mixture consisted of $2 \mu \mathrm{LRT}$ products, $2.5 \mu \mathrm{L}$ of $10 \times$ PCR buffer, $2 \mu \mathrm{L}$ of $25 \mathrm{mmol} / \mathrm{L} \mathrm{MgCl}_{2}, 2.5 \mu \mathrm{L}$ of $2 \mathrm{mmol} / \mathrm{L}$ dNTP mixture, $0.3 \mu \mathrm{L}$ primer $1(10 \mu \mathrm{mol} / \mathrm{L}), 0.3 \mu \mathrm{L}$ primer $2(10 \mu \mathrm{mol} / \mathrm{L}), 0.5 \mu \mathrm{L} 20 \times \mathrm{SYBR}$, and $0.3 \mu \mathrm{LDNA}$ Taq polymerase $(5 \mathrm{U} / \mu \mathrm{L})$. The PCR cycle was as follows: $94{ }^{\circ} \mathrm{C}$ for $2 \mathrm{~min}, 40$ cycles of $94^{\circ} \mathrm{C}$ for $1 \mathrm{~min}, 60^{\circ} \mathrm{C}$ for $1 \mathrm{~min}$, and $95^{\circ} \mathrm{C}$ for $15 \mathrm{~s}$ on a real-time PCR machine (Applied Biosystems 7000 Real Time PCR System, Foster City, CA 94404, USA). For the melting curve analysis after the PCR amplification, the fluorescence signal was measured at the end of the elongation phase at $84{ }^{\circ} \mathrm{C}$. The obtained mRNA level was expressed relative to that of the GAPDH (internal control) PCR product amplified from the same sample (sample PCR product/GAPDH PCR product).

Statistical analysis Quantitative variables were expressed as mean \pm SD. One-way ANOVA was used for the analysis. If any significant change was found, post-hoc comparisons were performed using Fisher's PLSD (Protected least significant difference). The ratio of amylin/insulin mRNA was assessed by the Mann-Whitney U-test. $P<0.05$ was considered significant.

\section{Results}

Fasting and post-prandial blood glucose Both the fast-
Table 1. Fasting/post-prandial blood glucose level in GK rats by 56 and $133 \mu \mathrm{g} / \mathrm{kg}$ subcutaneous rhGLP-1 (7-36) for 11 weeks. $n=15-$ 17. Mean \pm SD. ${ }^{\mathrm{c}} P<0.01$ vs Wistar group; ${ }^{\mathrm{e}} P<0.05$ vs $\mathrm{GK}$ group.

\begin{tabular}{lccc}
\hline \multirow{2}{*}{ Groups } & \multicolumn{3}{c}{ Blood glucose $(\mathrm{mmol} / \mathrm{L})$} \\
\cline { 2 - 4 } & $0 \mathrm{~min}$ & $30 \mathrm{~min}$ & $60 \mathrm{~min}$ \\
\hline GK & $7.98 \pm 2.88^{\mathrm{c}}$ & $14.10 \pm 3.52^{\mathrm{c}}$ & $22.44 \pm 2.84^{\mathrm{c}}$ \\
GK/GL & $6.99 \pm 2.59^{\mathrm{c}}$ & $10.80 \pm 1.08^{\mathrm{ce}}$ & $16.30 \pm 2.69^{\mathrm{ce}}$ \\
GK/GH & $8.14 \pm 3.42^{\mathrm{c}}$ & $12.00 \pm 2.88^{\mathrm{ce}}$ & $16.00 \pm 2.51^{\mathrm{ce}}$ \\
Wistar & $3.54 \pm 0.68$ & $4.84 \pm 0.86$ & $4.55 \pm 0.78$ \\
\hline
\end{tabular}

ing and post-prandial blood glucose levels were significantly higher in the untreated GK rats than the Wistar rats $(P<0.01$; Table 1). The GK/GLand GK/GH rats treated with 56 and 133 $\mu \mathrm{g} \cdot \mathrm{kg}^{-1}$ rhGLP-1 (7-36), showed significantly lower blood glucose levels at 30 and 60 min after feeding compared with the untreated GK group $(P<0.05$; Table 1$)$. There was no significant difference in the fasting blood glucose level $(P>0.05)$.

Levels of blood glucose in IPGTT Before the glucose administration, the fasting blood glucose levels were significantly higher in the GK rats than in the Wistar rats $(P<0.01$; Table 2 ). Following the intraperitoneal glucose injection in the GK rats, the blood glucose level at $15 \mathrm{~min}$ had risen to a greater extent than in the Wistar rats and continued to do so for the remainder of the experiment. The GK/GL and GK/GH rats treated with 56 and $133 \mu \mathrm{g} \cdot \mathrm{kg}^{-1} \mathrm{rhGLP}-1$ (7-36) showed significantly lower blood glucose levels after glucose loading compared with the untreated GK group $(P<0.05$; Table 2$)$. There was no significant difference at the fasting state $(P>0.05)$.

Amylin concentrations in plasma The plasma amylin levels were lower in the untreated GK rats than in the Wistar controls, both during basal conditions $(P<0.05)$ and after the glucose administration $(P<0.01$; Figure 1$)$. The basal plasma

Table 2. Level of blood glucose in GK rats by 56 and $133 \mu \mathrm{g} / \mathrm{kg}$ subcutaneous rhGLP-1 (7-36) in IPGTT. $n=15-17$. Mean \pm SD. ${ }^{\mathrm{c}} P<0.01$ vs Wistar group. ${ }^{\mathrm{e}} \mathrm{P}<0.05$ vs GK group.

\begin{tabular}{|c|c|c|c|c|c|c|}
\hline \multirow[t]{2}{*}{ Groups } & \multicolumn{6}{|c|}{ Blood glucose $(\mathrm{mmol} / \mathrm{L})$} \\
\hline & $0 \mathrm{~min}$ & $15 \min$ & $30 \mathrm{~min}$ & $60 \mathrm{~min}$ & $120 \mathrm{~min}$ & $180 \mathrm{~min}$ \\
\hline GK & $9.07 \pm 1.19^{\mathrm{c}}$ & $15.18 \pm 3.33^{\mathrm{c}}$ & $19.50 \pm 2.60^{\mathrm{c}}$ & $21.44 \pm 2.98^{c}$ & $25.14 \pm 2.37^{\mathrm{c}}$ & $28.83 \pm 4.21^{\mathrm{c}}$ \\
\hline GK/GL & $8.43 \pm 1.28^{c}$ & $12.76 \pm 2.82^{\mathrm{ce}}$ & $18.14 \pm 7.29^{\mathrm{c}}$ & $18.81 \pm 4.92^{\mathrm{c}}$ & $21.01 \pm 7.45^{\mathrm{c}}$ & $22.79 \pm 9.31^{\mathrm{ce}}$ \\
\hline GK/GH & $8.31 \pm 1.13^{\mathrm{c}}$ & $14.70 \pm 4.54^{\mathrm{c}}$ & $15.99 \pm 5.91^{\mathrm{c}}$ & $17.29 \pm 3.50^{\mathrm{c}}$ & $21.53 \pm 4.87^{\mathrm{c}}$ & $21.12 \pm 3.83^{\mathrm{ce}}$ \\
\hline Wistar & $4.31 \pm 0.30$ & $5.00 \pm 0.58$ & $4.96 \pm 0.46$ & $4.08 \pm 0.30$ & $3.27 \pm 0.25$ & $2.63 \pm 0.25$ \\
\hline
\end{tabular}




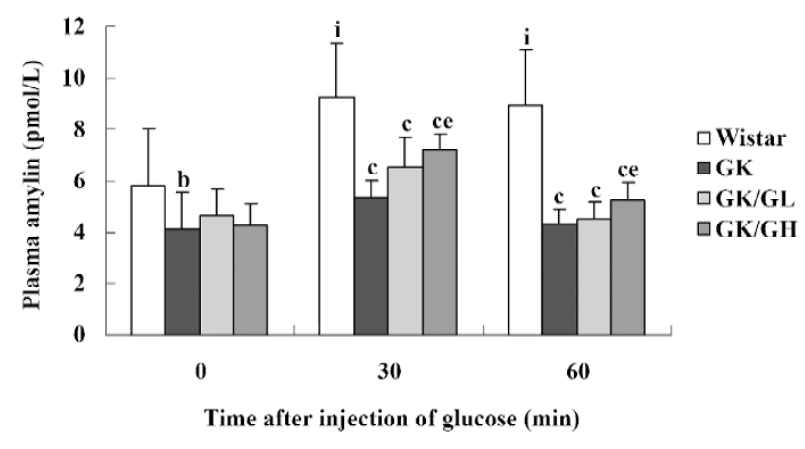

Figure 1. Plasma amylin levels after intraperitoneal injection of glucose $\left(1 \mathrm{~g} / \mathrm{kg}\right.$ body weight). $n=6-9$. Mean \pm SD. ${ }^{\mathrm{b}} P<0.05,{ }^{\mathrm{c}} P<0.01 \mathrm{vs}$ Wistar group. ${ }^{\mathrm{e}} P<0.05$ vs GK group. ${ }^{\mathrm{i}} P<0.01$ vs Wistar group at basal condition. GK/GL: GLP-1 $56 \mu \mathrm{g} \cdot \mathrm{kg}^{-1}$; GK/GH: GLP-1 $133 \mu \mathrm{g} \cdot \mathrm{kg}^{-1}$.

amylin levels in the GK/GL and GK/GH rats showed a descending trend compared to those in the untreated GK rats $(P>0.05)$. In response to the intraperitoneal glucose administration, the plasma amylin levels of the GK/GH rats displayed a marked increase at $30 \mathrm{~min}$ after the injection compared with the untreated GK rats $(P<0.05$; Figure 1$)$, whereas the increase in the GK/GL rats did not reach significance $(P=0.09)$. In the Wistar control rats, the levels had increased significantly at $30 \mathrm{~min}$, then remained at a similar level at 60 $\min (P<0.05$; Figure 1).

Histology and number of islets In contrast to the findings in the Wistar control rats (Figure 2A), the islets of the GK rats usually had a very irregular shape, and the islets sometimes had a broken appearance (Figure 2B). The boundary between the islets and exocrine pancreas was irregular. Some islet cells seemed degenerate and swollen. In many sections, a few islets were also found that displayed a rounded,

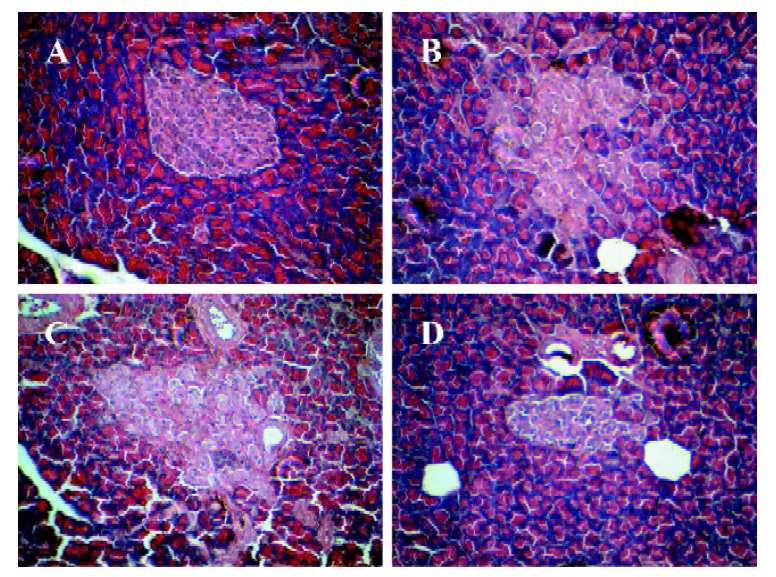

Figure 2. Histological examination of pancreas. (A) Wistar rats; (B) Untreated GK rats; (C) GK/GL rats; (D) GK/GH rats. GK/GL: GLP-1 $56 \mu \mathrm{g} \cdot \mathrm{kg}^{-1}$; GK/GH: GLP-1 $133 \mu \mathrm{g} \cdot \mathrm{kg}^{-1} . \times 250$.

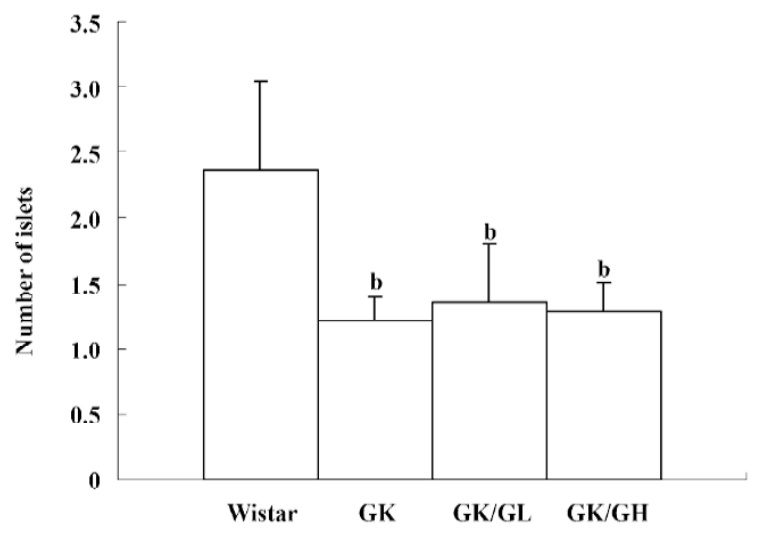

Figure 3. The number of islets of pancreas in observation field under microscopy. $n=4-5$. Mean \pm SD. ${ }^{\mathrm{b}} P<0.05$ s $\mathrm{Wistar}$ group. GK/ GL: GLP-1 $56 \mu \mathrm{g} \cdot \mathrm{kg}^{-1}$; GK/GH: GLP-1 $133 \mu \mathrm{g} \cdot \mathrm{kg}^{-1}$. $\times 250$.

clear-cut shape like the normal ones seen in the Wistar control rats. The number of islets was markedly decreased in the GK rats compared to the Wistar control rats $(P<0.01$; Figure 3$)$. No differences were found in the number of islets between the GK/GL or GK/GH rats and untreated GK rats. However, the GK/GL and GK/GH rats showed slight histological amelioration (Figure 2C,2D).

Immunohistochemistry finding Immunostaining for amylin showed conclusive positivity in many cells of the pancreatic islets in the Wistar rats (Figure 4A). The exocrine pancreata were completely negative for amylin. Few scattered cells were immunopositive for amylin in the untreated GK rats (Figure 4B). However, the GK/GL and GK/GH rats showed more rich amylin-positive cells compared to the untreated GK rats (Figure 4C,4D), although the positivelystained cells were still less than those of the Wistar rats.
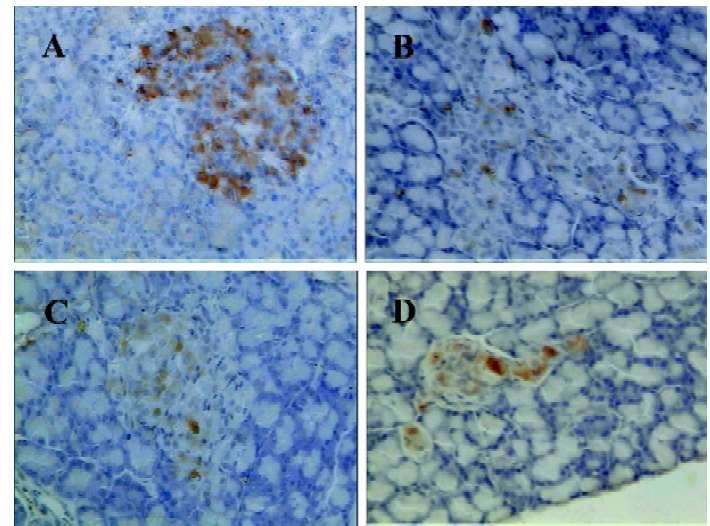

Figure 4. Amylin immunostaining (brown) in pancreatic tissue with anti-amulin antibody (sABC method). (A) Wister rats; (B) Untreaded GK rats; (C) GK/GL rats; (D) GK/GH rats. GK/GL: GLP-1 $56 \mu \mathrm{g} \cdot \mathrm{kg}^{-1}$; GK/GH: GLP-1 $133 \mu \mathrm{g} \cdot \mathrm{kg}^{-1} . \times 250$. 
Amylin and insulin mRNA levels In the untreated GK rats, the levels of amylin and insulin mRNA were significantly reduced $(P<0.01)$. However, there was a more pronounced reduction in the levels of insulin mRNA than amylin mRNA. The levels of insulin mRNA in the untreated GK rats was $24 \%$ of that of the Wistar controls, whereas the levels of amylin mRNA in untreated GK rats was 59\% of that of the Wistar controls. The GK/GL and GK/GH rats both showed marked increases of amylin and insulin mRNA compared with the untreated GK rats (Figure 5).

\section{A}

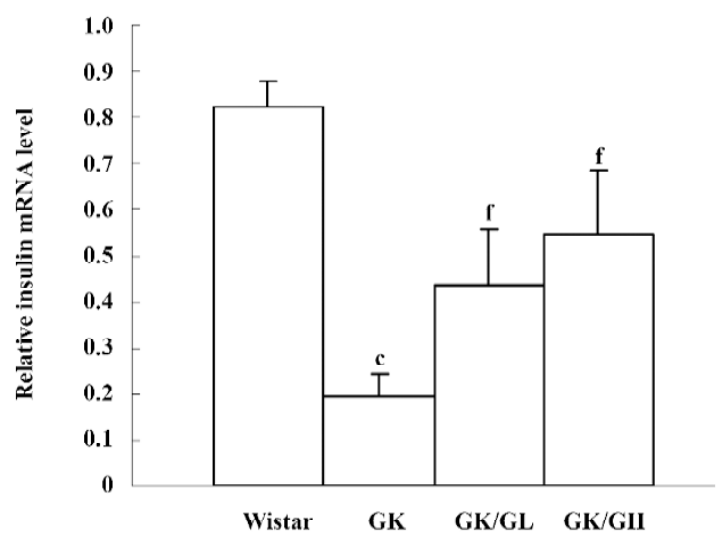

B

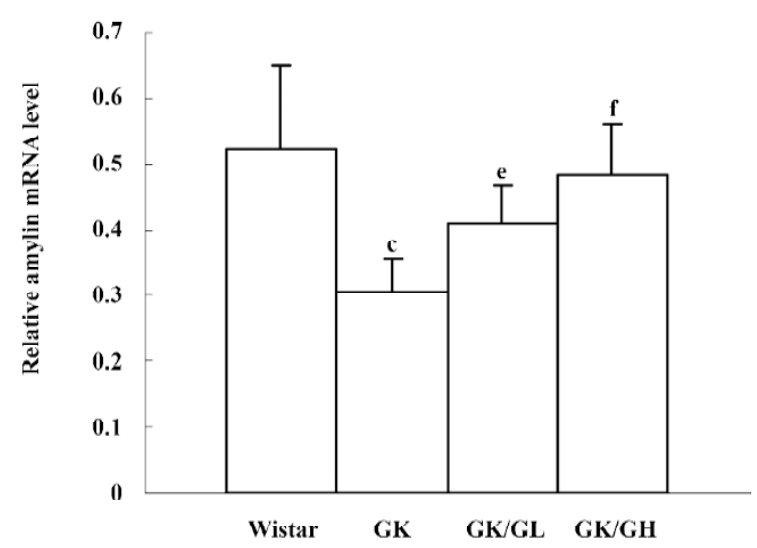

Figure 5. The levels of insulin (A) and amylin (B) mRNA in pancreas tissues by FQ-PCR. $n=6-9$. Mean \pm SD. ${ }^{\mathrm{c}} P<0.01 \mathrm{vs}$ Wistar group. ${ }^{\mathrm{e}} P<0.05,{ }^{\mathrm{f}} P<0.01$ vs GK group. GK/GL: GLP-1 $56 \mu \mathrm{g} \cdot \mathrm{kg}^{-1} ; \mathrm{GK} /$ GH: GLP-1 $133 \mu \mathrm{g} \cdot \mathrm{kg}^{-1}$.

The amylin to insulin mRNA ratio of the untreated GK rats was significantly higher than that of the Wistar rats $(P<0.05$, $164.51 \% \pm 43.86 \%$ vs $63.25 \% \pm 13.76 \%$ ). The ratioin the GK/GL and GK/GH rats was decreased with the rhGLP-1 (7-36) treatment compared to the untreated GK rats $(P<0.05$; Figure 6$)$.

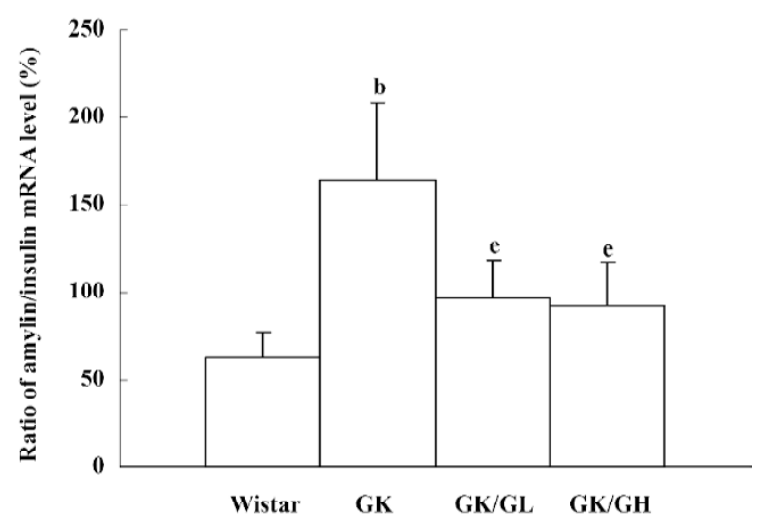

Figure 6. The ratio of amylin/insulin mRNA levels in pancreas tissues. $n=6-9$. Mean \pm SD. ${ }^{\mathrm{b}} P<0.05$ vs Wistar group. ${ }^{\mathrm{e}} P<0.05$ vs $\mathrm{GK}$ group. GK/GL: GLP-1 $56 \mu \mathrm{g} \cdot \mathrm{kg}^{-1}$; GK/GH: GLP-1 $133 \mu \mathrm{g} \cdot \mathrm{kg}^{-1}$.

\section{Discussion}

Type 2 diabetes is characterized by insulin resistance and progressive $\beta$-cell dysfunction leading to insulin deficiency $^{[21]}$. The importance of aggressive glucose-lowering therapy to prevent late diabetes complications in type 2 diabetes has been convincingly established ${ }^{[22,23]}$. However, the UK-PDS also demonstrated that the antidiabetic treatment used failed to maintain acceptable glycemic control in the vast majority of patients, emphasizing the need for more effective antidiabetic agents. Treatment failure was attributed to progressive $\beta$-cell exhaustion in type 2 diabetes. Recently, amylin has been suggested to be responsible for $\beta$-cell failure during the progression of type 2 diabetes ${ }^{[1]}$.

GLP-1 has been shown to acutely reduce plasma glucose levels by increasing insulin release and synthesis, inhibiting glucagon release, and decreasing gastric emptying and appetite. Long-term beneficial effects have also been shown in human and rodent model $\mathrm{s}^{[24,25]}$. These findings indicate that GLP-1 is potentially a very attractive agent for treating type 2 diabetes. In the present study, we investigated the effects of 12 weeks of treatment with rhGLP-1 (7-36) on blood glucose and hormone profiles. Treatment with 56 and 133 $\mu \mathrm{g} \cdot \mathrm{kg}^{-1} \mathrm{RhGLP}-1$ (7-36) treatment markedly improved the glucose tolerance and reduced the blood glucose level of GK rats after glucose loading, whereas no difference was observed in the fasting glucose level. The result was possibly attributed to the short half-life of GLP-1 (7-36). GLP-1 (7-36) was rapidly degraded by the ubiquitous enzyme dipeptidyl peptidase IV ${ }^{[26]}$. This enzyme, which is present in the bloodstream and on cell membranes, cleaves the GLP-1 (7-36) peptide to yield the inactive GLP-1 (9-36) form. Therefore, the subcutaneous injection tid treatment of the GLP-1 (7-36) pep- 
tide is probably insufficient in ensuring the effective plasma concentration of the GLP-1 (7-36) peptide, which results in the loss of glycemic control and decreased glucose toxicity.

As we known, amyloid deposition, which is composed of amylin, is a predominant factor resulting in $\beta$-cell failure in type 2 diabetes ${ }^{[1]}$. In our study, few scattered cells were immunopositive for amylin in the pancreatic islets of the untreated GK rats compared to the Wistar rats. This finding may indicate that the amylin content decreased in the islet secretory cells of the GK rats. However, the GLP-1 (7-36) treatment caused more abundant amylin-positive cells compared to the untreated GK rats. That is, GLP-1 (7-36) increased the amylin content. We then tested the plasma amylin concentration after the glucose administration. The result was consistent with the change of content. GLP-1 (736) elevated the levels of plasma amylin in response to the intraperitoneal glucose administration. A limitation of our study was that we only measured 3 time points after the intraperitoneal glucose administration due to the low plasma sample amount. Nevertheless, the parallel relationship between the amylin content and amylin secretion was clear and was consistent with previous studies ${ }^{[27]}$. However, the increase in the production and secretion of amylin may be an important contributor to amyloid fibril formation. That is, GLP-1 (7-36) may promote the formation of amyloid deposition, but is this true?

To answer this question, we designed the protocol to investigate the effect of GLP-1 (7-36) on the amylin mRNA level. The present study, using FQ-PCR, examined the changes in the amylin and insulin mRNA levels in GLP-1 (7-36)-treated GK rats. In the untreated GK rats, the quantitative findings revealed a marked reduction of the amylin and insulin mRNA in the islets, whereas the level of amylin mRNA was less reduced than that of insulin mRNA. Therefore, the ratio of amylin to insulin mRNA was sharply increased in the untreated GK rats compared to the Wistar rats, which was almost 2-fold higher. It has been proposed that the amylin/ insulin ratio may be worth investigating rather than the absolute amylin mRNA level. It is not clear whether the increase in the amylin/insulin mRNA ratio in GK rats is a primary feature or is secondary to hyperglycemia. Interestingly, hyperglycemia results in the hypersecretion of amylin relative to that of insulin as well as increasing the amylin /insulin ratio in insulin-resistant rats. Furthermore, it was recently shown that the level of amylin mRNA increased more than that of insulin mRNA in insulinoma cell line, INS-1 cells, cultured in a medium containing $100 \mu \mathrm{mol} / \mathrm{L}$ isobutylmethylxanthine ${ }^{[28]}$. Thus it is not inconceivable that the expression of amylin may be more sensitive to hyperglycemia and peripheral insulin re- sistance than that of insulin under certain conditions. An increased ratio of amylin/insulin expression seems to be a marker for insulin cell dysfunction under certain conditions.

In our research, the treatment with GLP-1 (7-36) significantly increased the amylin and insulin mRNA levels, but markedly decreased the ratio of amylin/insulin mRNA in the GK rats. This result further confirms that GLP-1 (7-36) stimulated an augmentation of the secretion and expression of amylin in islet cells, which was consistent with other findings. An increase of insulin protein expression was also certified in the GK rats treated with GLP-1 (7-36) by immunohistochemistry ${ }^{[29]}$. Therefore, it is not clear whether the augmentation resulted from the either the direct effect of GLP-1 (7-36) on stimulating amylin or the secondary effect of GLP-1 (7-36) on stimulating insulin. Our other interest was in exploring the influence of GLP-1 (7-36) treatment on the decreased the ratio of amylin/insulin mRNA. The result contributes notably to the clinical treatment of GLP-1 (7-36) in type 2 diabetes, including pathophysiological changes. $\mathrm{Pu}-$ tative mechanisms promote amylin gene expression separate from insulin gene expression. However, the effect of GLP-1 (7-36) on the pathways and sites of amylin and insulin gene expression regulation require further study.

\section{Acknowledgments}

We wish to thank Shanghai Slac Laboratory Animals for the animal breeding.

\section{References}

1 Marzban L, Park K, Verchere CB. Islet amyloid polypeptide and type 2 diabetes. Exp Gerontol 2003; 38: 347-51.

2 Jaikaran ET, Clark A. Islet amyloid and type 2 diabetes: from molecular misfolding to islet pathophysiology. Biochim Biophys Acta 2001; 1537: 179-203.

3 Westermark P, Wernstedt C, Wilander E, Hayden DW, O'Brien TD, Johnson KH. Amyloid fibrils in human insulinoma and islets of Langerhans of the diabetic cat are derived from a neuronpeptide-like protein also present in normal islet cells. Proc Natl Acad Sci USA 1987; 84: 3881-5.

4 Kahn SE, D’Alessio DA, Schwartz MW, Fujimoto WY, Ensinck JW, Taborsky GJ Jr, et al. Evidence of cosecretion of islet amyloid polypeptide and insulin by $\beta$-cells. Diabetes 1990; 39: 634-8.

5 Kahn SE, Andrikopoulos S, Verchere CB. Islet amyloid: a longrecognized but underappreciated pathological feature of type 2 diabetes. Diabetes 1999; 48: 241-53.

6 Ludvik B, Thomaseth K, Nolan JJ, Clodi M, Prager R, Pacini G. Inverse relation between amylin and glucagon secretion in healthy and diabetic human subjects. Eur J Clin Invest 2003; 33: 316-22.

7 Verchere CB, D'Alessio DA, Prigeon RL, Hull RL, Kahn SE. The constitutive secretory pathway is a major route for islet amyloid polypeptide secretion in neonatal but not adult rat islet cells. 
Diabetes 2000; 49: 1477-84.

8 Rachman J, Payne MJ, Levy JC, Barrow BA, Holman RR, Turner $\mathrm{RC}$, et al. Changes in amylin and amylin-like peptide concentrations and $\beta$-cell function in response to sulfonylurea or insulin therapy in NIDDM. Diabetes Care 1998; 21: 810-6.

9 Dhanvantari S, Izzo A, Jansen E, Brubaker PL. Coregulation of glucagon-like peptide-1 synthesis with proglucagon and prohormone convertase 1 gene expression in enteroendocrine GLUTag cells. Endocrinology 2001; 142: 37-42.

10 Vilsbøll T, Krarup T, Deacon CF, Madsbad S, Holst JJ. Reduced postprandial concentrations of intact biologically active glucagon-like peptide 1 in type 2 diabetic patients. Diabetes 2001; 50: 609-13.

11 Brubaker PL, Drucker DJ. Mini review: glucagon-like peptides regulate cell proliferation and apoptosis in the pancreas, gut, and central nervous system. Endocrinology 2004; 145: 2653-9.

12 Zander M, Madsbad S, Madsen JL, Holst JJ. Effect of 6-week course of glucagon-like peptide 1 on glycaemic control, insulin sensitivity, and $\beta$-cell function in type 2 diabetes: a parallelgroup study. Lancet 2002; 359: 824-30.

13 Kjems LL, Holst JJ, Vølund A, Madsbad S. The influence of GLP1 on glucose-stimulated insulin secretion: effects on $\beta$-cell sensitivity in type 2 and nondiabetic subjects. Diabetes 2003; 52: 380-6.

14 Portha B, Serradas P, Bailbé D, Suzuki K, Goto Y, Giroix MH. $\beta$ Cell insensitivity to glucose in the GK rat, a spontaneous nonobese model for type II diabetes. Diabetes 1991; 40: 486-91.

15 Ostenson CG, Khan A, Abdel-Halim SM, Guenifi A, Suzuki K, Goto Y, et at. Abnormal insulin secretion and glucose metabolism in pancreatic islets from the spontaneously diabetic GK rat. Diabetologia 1993; 36: 3-8.

16 Rolin B, Larsen MO, Gotfredsen CF, Deacon CF, Carr RD, Wilken $\mathrm{M}$, et al. The long-acting GLP-1 derivative NN2211 ameliorates glycemia and increases $\beta$-cell mass in diabetic mice. Am J Physiol Endocrinol Metab 2002; 283: E745-52.

17 Wang Y, Perfetti R, Greig NH, Holloway HW, DeOre KA, Montrose-Rafizadeh $\mathrm{C}$, et al. Glucagon-like peptide-1 can reverse the age-related decline in glucose tolerance in rats. $\mathrm{J}$ Clin Invest 1997; 99: 2883-9.

18 Buse JB, Weyer C, Maggs DG. Amylin replacement with pramlintide in type 1 and type 2 diabetes: a physiological approach to overcome barriers with insulin therapy. Clin Diabetes 2002; 20: 137-44.

19 Rotondo F, Vidal S, Bell D, Horvath E, Kovacs K, Scheithauer $\mathrm{BW}$, et al. Immunohistochemical localization of amylin in human pancreas, thyroid, pituitary and their tumors. Acta Histochem 2003; 105: 303-7.

20 Leckström A, Ostenson CG, Efendiæ S, Arnelo U, Permert J, Lundquist I, et al. Increased storage and secretion of islet amyloid polypeptide relative to insulin in the spontaneously diabetic GK rat. Pancreas 1996; 13: 259-67.

21 Ferrannini E. Insulin resistance versus insulin deficiency in noninsulin-dependent diabetes mellitus: problems and prospects. Endocr Rev 1998; 19: 477-90.

22 Mokdad AH, Ford ES, Bowman BA, Dietz WH, Vinicor F, Bales VS, et al. Prevalence of obesity, diabetes, and obesity-related health risk factors, 2001. JAMA 2003; 289: 76-9.

23 Gaede P, Vedel P, Larsen N, Jensen GV, Parving HH, Pedersen O. Multifactorial intervention and cardiovascular disease in patients with type 2 diabetes. N Engl J Med 2003; 348: 383-93.

24 Drucker DJ. Mini review: the glucagon-like peptides. Endocrinology 2001; 142: 521-7.

25 Kieffer TJ, Habener JF. The glucagon-like peptides. Endocr Rev 1999; 20: 876-913.

26 Deacon CF, Nauck MA, Toft-Nielsen M, Pridal L, Willms B, Holst JJ. Both subcutaneously and intravenously administered glucagon-like peptide I are rapidly degraded from the $\mathrm{NH}_{2}$-terminus in type II diabetic patients and in healthy subjects. Diabetes 1995; 44: 1126-31.

27 Leahy JL, Fineman MS. Impaired phasic insulin and amylin secretion in diabetes rats. Am J Physiol 1998; 275: E457-62.

28 Cluck MW, Murphy LO, Olson J, Knezetic JA, Adrian TE. Amylin gene expression mediated by cAMP/PKA and transcription factors HNF-1 and NFY. Mol Cell Endocrinol 2003; 210 : $63-75$.

$29 \mathrm{Gu}$ Q, Gao X. Effect of recombined human glucagon-like peptide-1 on body weight, blood glucose metabolism and $\beta$-cell function and mass in GK rat. Fudan Univ J Med Sci 2007; 34: 1115. 